\title{
Th17 expansion in granulomatosis with polyangiitis (Wegener's): the role of disease activity, immune regulation and therapy
}

Benjamin Wilde ${ }^{1,2}$, Marielle Thewissen ${ }^{1}$, Jan Damoiseaux ${ }^{3}$, Marc Hilhorst ${ }^{1}$, Pieter van Paassen ${ }^{1}$, Oliver Witzke ${ }^{2}$ and Jan Willem Cohen Tervaert ${ }^{1,3^{*}}$

\begin{abstract}
Introduction: In autoimmune diseases, IL-17 producing T-cells (Th17), a pro-inflammatory subset of T-cells, are pathophysiologically involved. There is little knowledge on the role of Th17 cells in granulomatosis with polyangiitis (GPA). In the present study, we investigated Th17 cells, Tregs and subsets of circulating Th17 cells in GPA and related results to disease activity.
\end{abstract}

Methods: 42 GPA patients in remission, 18 with active disease and 14 healthy controls (HC) were enrolled. Th17 cells, their subsets and regulatory T-cells were determined by intracellular fluorescence activated cell sorter (FACS). Data are given as mean percentage \pm SD of total T-helper-cells.

Results: Th17 cells are expanded in active and quiescent GPA as compared to HC $(1.7 \pm 1.4 \%$ vs. $0.7 \pm 0.3 \%, P=$ 0.006 and $1.9 \pm 1.5 \%$ vs. $0.7 \pm 0.3 \%, P<0.0001)$. Th17 expansion is stable over time and does not decline when remission is achieved. However, a negative association of Th17 cells and steroid dosage is observed $(r=-0.46, P=$ 0.002). The Th17 expansion was not balanced by Tregs as indicated by skewed Th17/Treg ratios in active and quiescent GPA. Th17 subsets co-producing IFN $\gamma$ or IL-10 are significantly increased in GPA. GPA patients in remission not receiving maintenance therapy have significantly more IL-10/L-17A double positive T-cells than HC $(0.0501 \pm 0.031 \%$ vs. $0.0282 \pm 0.016 \%, P=0.007)$.

Conclusions: We provide evidence for a persistent, unbalanced expansion of Th17 cells and Th17 subsets which seems to be independent of disease activity. Maintenance therapy reduces -but does not normalize- Th17 expansion.

\section{Introduction}

Granulomatosis with polyangiitis (GPA) is an autoimmune form of necrotizing small-vessel vasculitis characterized by the presence of antineutrophil cytoplasmic antibodies (ANCA). GPA is strongly associated with ANCA directed against proteinase-3 (PR3) and in a minority of cases, ANCA with specificity for myeloperoxidase (MPO) are detected [1-3]. Alongside the role of the autoantibodies in disease pathogenesis, $T$ cells also contribute to disease mechanisms as suggested by the isotype of ANCA, which indicates that a $\mathrm{T}$ cell-dependent class-switch has taken

\footnotetext{
* Correspondence: jw.cohentervaert@maastrichtuniversity.nl

'Department of Internal Medicine, Division of Clinical and Experimental Immunology, University Hospital Maastricht, PO Box 5800, Maastricht, 6202 $A Z$, The Netherlands

Full list of author information is available at the end of the article
}

place [4]. Furthermore, T cells are present in inflammatory lesions related to GPA and it is thought that granuloma formation in GPA is T cell-dependent [5-7]. Accordingly, deviation of circulating $\mathrm{T}$ cells has been described in GPA showing persistent $\mathrm{T}$ cell activation, expansion of memory $\mathrm{T}$ cells and a deficient function of regulatory $\mathrm{T}$ cells [8-14].

Th17 cells were recently described as a separate $\mathrm{T}$-helper-cell lineage with distinct features $[15,16]$. IL$17 \mathrm{~A}$ is a signature cytokine of this T-helper-cell lineage. IL-17A drives inflammation by promoting neutrophil/ macrophage recruitment, enhances auto-antibody production and facilitates tissue destruction by upregulation of matrix metalloproteases $[17,18]$. A role for Th17 cells has been established in autoimmune diseases such as giant cell arteritis (GCA), rheumatoid arthritis (RA) and 
systemic lupus erythematosus (SLE) $[17,19-22]$. In these diseases, increased circulating Th17 cells have been closely associated to disease activity.

Also in GPA, a pathogenic role of Th17 cells is likely. Gan et al. showed in an animal model of experimental MPO-vasculitis that IL-17A deficiency attenuated the disease [23]. In addition, the frequency of auto-antigenspecific Th17 cells in convalescent ANCA-vasculitis is increased $[24,25]$. Another study by Fagin et al. showed that auto-antigen-specific Th17 cells, including IL-17A/ IFN $\gamma$ and IL-17A/IL-4 double producers, were also increased in active ANCA-vasculitis [26]. The role of auto-antigen-specific $\mathrm{T}$ cells in the initiation of autoimmunity is controversial. Ghani et al. found that antigenspecific $\mathrm{T}$ cells condition inflamed sites for high-rate antigen non-specific effector $T$ cell recruitment [27]. In contrast, Murakami et al. recently reported that antigen specificity is of limited importance to initiate autoimmune processes [28]. In an experimental mouse model, activated Th17 cells were able to initiate arthritis in the absence of cognate antigen recognition [28]. Since comparable non-antigen-dependent mechanisms might be operative in GPA, we investigated 1) the presence of circulating Th17 cells in active and quiescent GPA, 2) whether Th17 expansion is balanced by regulatory $\mathrm{T}$-cell subsets, and 3) concomitant expression of different cytokines in Th17 cells.

\section{Materials and methods Patient cohort}

We enrolled 60 patients with GPA, (12 with MPO-ANCA, 48 with PR3-ANCA, Table 1), mean age ( \pm SD) 57 ( \pm 13 ) years, and 14 age-matched healthy volunteers (healthy controls, HC), mean age $53 \pm 5$ years. Eighteen patients were in an active state of disease at presentation and fortytwo were in remission (Table 1,2). Informed patient consent and approval by the local ethics committee was obtained. Seven patients initially presenting with active disease were assessed again after remission was achieved. The diagnosis and classification of GPA was made according to criteria of the American College of Rheumatology, the Chapel Hill criteria and the algorithm published by
Watts et al. [29-31]. Active disease was defined as clinical manifestation of new-onset or recurrent disease activity related to vasculitis requiring intensified immunosuppressive therapy $[32,33]$. All patients with active disease were either untreated or treated with maintenance therapy at the time of sampling. None of the active patients had received cyclophosphamide or high dose intravenous methylprednisolone at the time of sampling. Remission or quiescent disease was defined as absence of clinical disease activity reflecting a Birmingham Vasculitis Activity Score of zero [33]. The cohort of patients in remission was divided for further analysis into two groups: patients in long-term stable remission, and patients with a relapsing disease course. Patients with a relapse-free disease course since the first onset of GPA and a minimum disease duration of 48 months, were defined as being in stable longterm remission $(\mathrm{n}=13)$. Patients with a minimum disease duration of 48 months and at least one relapse within the first 48 months since diagnosis of GPA were defined as relapsers $(n=19)$.

\section{Flow cytometry: staining of surface antigens}

Lymphocyte phenotypes were measured by five-colour surface staining. The following antibodies labeled with fluorescent dye were used: CD3 (mouse IgG1, HorV450), CD4 (mouse IgG1, PerCP; ITK/Biolegend, Uithoorn, The Netherlands), CD8 (mouse IgG1, APC-H7), CD25 (mouse IgG1, FITC), CD127 (mouse IgG1, PE). All antibodies except CD4 were purchased at BD Bioscience, Breda, The Netherlands. Appropriate isotype controls (BD Bioscience) were used. Peripheral blood mononuclear cells (PBMC) were isolated by standard Ficoll density gradient centrifugation (Histopaque; Sigma Aldrich, Zwijndrecht, The Netherlands) and incubated with labeled monoclonal antibodies for 30 minutes in the dark at room temperature. Analysis was performed with a fluorescence-activated cell sorter (FACS) CANTO ${ }^{\mathrm{TM}}$ from BD Bioscience.

\section{Immunostaining for intracellular cytokines}

PBMC from patients and $\mathrm{HC}$ were separated by standard Ficoll density gradient centrifugation. The cells were resuspended in RPMI 1640 medium (Gibco Invitrogen,

Table 1 Clinical characteristics of the patient cohort

\begin{tabular}{lcc}
\hline Characteristic & Remission & Active disease \\
\hline Number & 42 & 18 \\
Age, years, mean \pm SD & $58 \pm 13$ & $54 \pm 14$ \\
PR3/MPO & $37 / 5$ & $11 / 7$ \\
Disease duration, months, mean \pm SD & $105 \pm 75$ & $67 \pm 97$ \\
Treatment, yes/no & $16 / 26$ & $7 / 11$ \\
Steroids, yes/no & $13 / 3$ (12 patients: 5 to $10 \mathrm{mg} ; 1$ patient: $30 \mathrm{mg})$ & $7 / 0$ (4 patients: 5 to $10 \mathrm{mg} ;$ to $45 \mathrm{mg})$ \\
AZA/MMF/MTX/CYC & $7 / 2 / 4 / 0$ & $2 / 1 / 0 / 0$ \\
\hline
\end{tabular}

PR3/MPO, proteinase-3/myeloperoxidase (describes the anti-neutrophil-cytoplasmic antibodies specificity at the time of diagnosis); AZA, azathioprine; CYC, cyclophosphamide; MMF, mycophenolate mofetil; MTX, methotrexate. 
Table 2 Characteristics of patients with active disease at the time of sampling

\begin{tabular}{|c|c|c|c|c|c|c|}
\hline Patient number & Age (years) & ANCA type & Disease duration (months) & Disease activity at time of sampling & BVAS & CRP (mg/L) \\
\hline 1 & 55 & PR3 & 0 & $\mathrm{~A}, \mathrm{ENT}, \mathrm{K}, \mathrm{L}$ & 25 & 292 \\
\hline 2 & 37 & PR3 & 44 & A, ENT & 5 & 20 \\
\hline 3 & 55 & PR3 & 57 & $A, K, L$ & 15 & 247 \\
\hline 4 & 58 & MPO & 120 & A, L & 7 & 23 \\
\hline 5 & 49 & PR3 & 190 & A, ENT, L & 10 & 46 \\
\hline 6 & 57 & PR3 & 259 & Ey, ENT & 6 & $<5$ \\
\hline 7 & 56 & PR3 & 191 & Ey & 6 & $<5$ \\
\hline 8 & 82 & MPO & 0 & $L$ & 4 & 44 \\
\hline 9 & 53 & PR3 & 0 & $\mathrm{~A}, \mathrm{ENT}, \mathrm{K}, \mathrm{L}$ & 17 & 160 \\
\hline 10 & 74 & PR3 & 0 & K & 10 & NA \\
\hline 11 & 69 & PR3 & 9 & ENT, K & 14 & 211 \\
\hline 12 & 41 & MPO & 0 & $\mathrm{~A}, \mathrm{ENT}, \mathrm{K}, \mathrm{S}$ & 17 & 44 \\
\hline 13 & 58 & MPO & 0 & ENT, K, S & 14 & 116 \\
\hline 14 & 70 & MPO & 0 & A, ENT, K, L & 19 & 188 \\
\hline 15 & 53 & PR3 & 15 & Ey, K & 12 & 12 \\
\hline 16 & 24 & PR3 & 9 & A, Ey & 3 & 16 \\
\hline 17 & 40 & MPO & 33 & ENT & 6 & $<5$ \\
\hline 18 & 41 & MPO & 284 & $\mathrm{~K}, \mathrm{~L}$ & 12 & $<5$ \\
\hline
\end{tabular}

None of the patients received induction therapy at the time of sampling. PR3/MPO, proteinase-3/myeloperoxidase; this reflects anti-neutrophil-cytoplasmic antibodies specificity (ANCA) at the time of diagnosis. Organ involvement of patients with active disease at the time of sampling is depicted. A, arthritis (joints); BVAS, Birmingham Vasculitis Activity Score; CRP, C-reactive protein; ENT, ear-nose-throat; Ey, ophthalmologic manifestation of disease; K, kidney; L, lung; S, skin.

Breda, The Netherlands) supplemented with $10 \%$ heatinactivated fetal calf serum (Greiner Bio-One, Alphen a/d Rijn, The Netherlands), $100 \mathrm{U} / \mathrm{mL}$ penicillin and $100 \mu \mathrm{g} /$ $\mathrm{mL}$ Streptomycin (both Gibco Invitrogen). The cells were cultured in the absence or presence of PMA $(50 \mathrm{ng} / \mathrm{mL})$ and Ionomycin $(1 \mu \mathrm{g} / \mathrm{mL})$ (Sigma-Aldrich) for 4 hours. Cytokine secretion was inhibited by Brefeldin A (BD Bioscience). Surface staining was performed with $C D 3$ HorV450 and CD8 APC-H7 (both BD Bioscience). Cells were fixed using a Cytofix/Cytoperm kit (BD Bioscience). Finally, the samples were stained intracellularly for CD69 (ITK/Biolegend), IFN $\gamma$ (BD Bioscience), IL-4, IL-10 and IL-17A (all ITK/Biolegend). Unstimulated PBMC and appropriate isotype controls were used to confirm specificity of staining and to discriminate background staining. FSC-H vs. FSC-A gating allowed exclusion of cell doublets. As stimulation with PMA/ionomycin induced downregulation of CD4, $\mathrm{CD} 4^{+} \mathrm{T}$ cells were defined as $\mathrm{CD} 3^{+} \mathrm{CD} 8^{\text {neg }}$, and an average of 30,000 events was acquired in this $\mathrm{CD} 3^{+} \mathrm{CD} 8^{\text {neg }}$ gate. CD69 expression was used as a control for the activation procedure but was not included in the gating strategy. CD69 expression did not differ between $\mathrm{HC}$ and patients with GPA after mitogen stimulation $(94.97 \pm 3.49 \%$ vs. $95.25 \pm 3.54 \%$, $P>0.05)$.

\section{Statistics}

All values are expressed as mean \pm SD. Significance for the differences between groups was determined using the Mann-Whitney $U$-test. Spearman's rank correlation test was applied to detect correlation between different study parameters.

\section{Results}

Circulating Th17 cells are increased during active disease and remain elevated during remission

Patients with active GPA $(n=18)$ showed a significantly increased percentage of circulating IL- $17 \mathrm{~A}^{+} \mathrm{T}$ cells compared to $\mathrm{HC}(\mathrm{n}=14)\left(\%\right.$ of $\mathrm{CD}^{+} \mathrm{T}$ cells $=1.7 \pm 1.4 \%$ vs. $0.7 \pm 0.3 \%, P=0.006$ (Figure $1 \mathrm{~A}, \mathrm{~B}$ ), while there was no difference in IFN $\gamma(14.5 \pm 9.9 \%$ vs. $17.7 \pm 7.9 \%, P=0.17)$, or IL-4-producing CD $4^{+} \mathrm{T}$ cells $(5.6 \pm 3.3 \%$ vs. $4.9 \pm$ $2.1 \%, P=0.7)$. There were no significant differences between active patients with or without maintenance therapy at the time of sampling.

Th17 expansion was similar between active GPA and quiescent GPA ( $\mathrm{n}=42,1.7 \pm 1.4 \%$ vs. $1.9 \pm 1.5 \%, P=$ 0.37 (Figure 1B). Seven patients first assessed during the active state of disease were sampled again during remission (median time between visits 118 days, range 71 to 567 days). The percentage of Th17 cells did not decline during remission (Figure $1 \mathrm{C}$ ).

Accordingly, circulating IL-17A ${ }^{+} \mathrm{T}$ cells were elevated in GPA patients in remission compared to $\mathrm{HC}$ (\% of CD4 ${ }^{+}$ T cells $=1.9 \pm 1.5 \%$ vs. $0.7 \pm 0.3 \%, P<0.0001$ ) (Figure $1 \mathrm{~A}$, B) whereas IFN $\gamma(22.1 \pm 10.8 \%$ vs. $17.7 \pm 7.9 \%, P=0.20)$, and IL-4 producing-T-helper-cells $(6.1 \pm 2.5 \%$ vs. $4.9 \pm$ $2.1 \%, P=0.11$ ) did not differ between patients with GPA and the $\mathrm{HC}$. Of note, IFN $\gamma^{+} \mathrm{T}$-cells were significantly reduced in patients with active GPA compared to those 


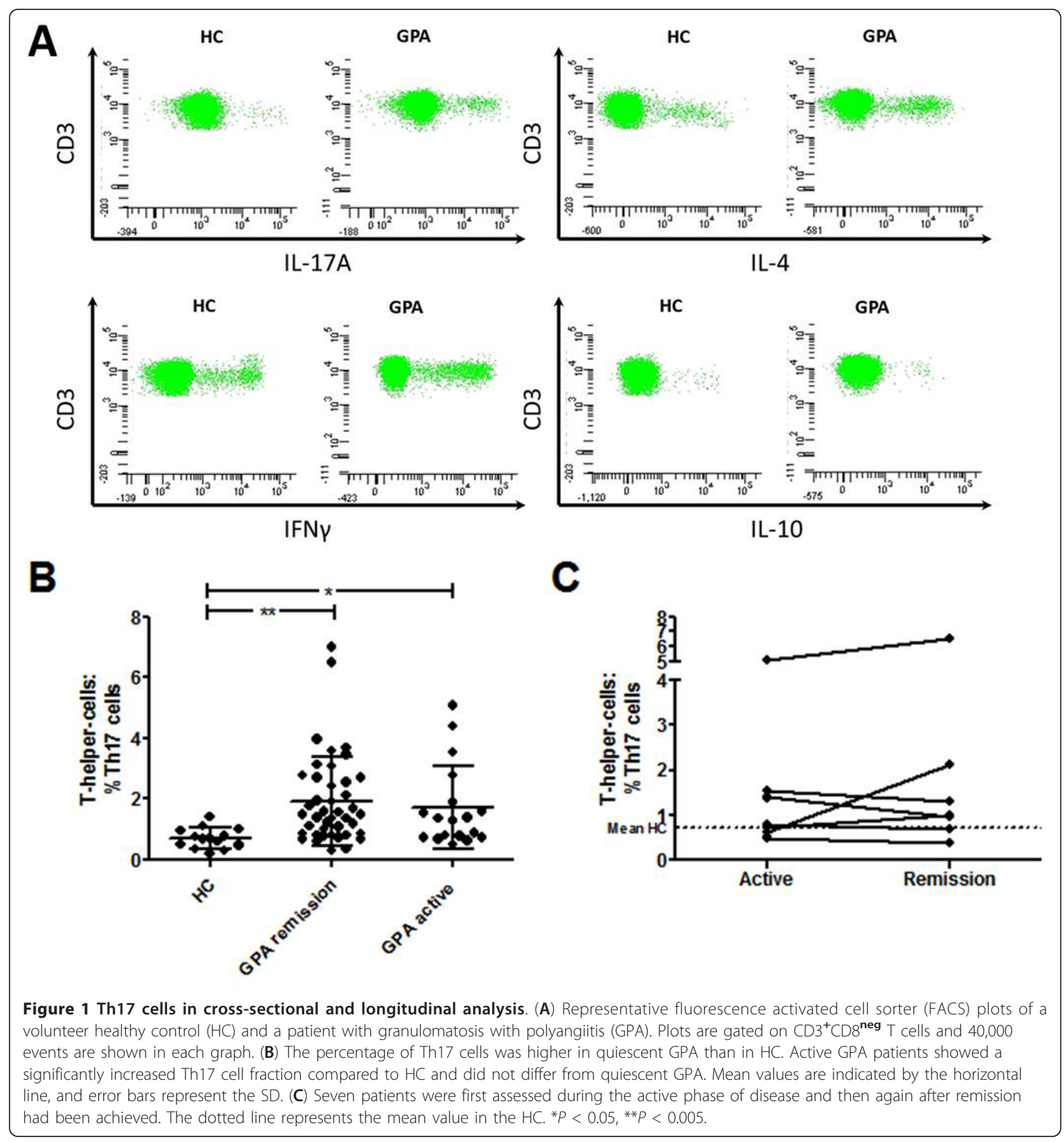

with quiescent disease $(14.5 \pm 9.9 \%$ vs. $22.1 \pm 10.8 \%, P=$ 0.002).

$\mathrm{CD}^{+} \mathrm{CD} 4^{\text {neg }} \mathrm{CD}^{\text {neg }}$ (DN) $\mathrm{T}$-cells were previously described as producers of IL-17 [34]. However, there was no difference between $\mathrm{HC}$ and patients with GPA in the percentage of $\mathrm{DN} \mathrm{T}$ cells $\left(\%\right.$ of $\mathrm{CD}^{+} \mathrm{T}$-cells in the $\mathrm{HC}$ vs. quiescent $\mathrm{GPA}=2.9 \pm 2.0 \%$ vs. $3.1 \pm 2.9 \%$, $P>0.05$, and in the $\mathrm{HC}$ vs. active $\mathrm{GPA}=2.9 \pm 2.0 \%$ vs. $3.4 \pm 4.1 \%, P>0.05)$. Moreover, DN T cells did not correlate with Th17 cells $(r=-0.4, P=0.2$ in the HC; $r=-0.3, P=0.3$ in patients with GPA).

\section{Clinical associations with Th17 cells in GPA}

ANCA-status, that is, PR3/MPO-ANCA negative ( $\mathrm{n}=$ 12) vs. positive $(n=30)$ at the time of sampling, did not have impact on the percentage of Th17 cells (data not shown). Patients with $(\mathrm{n}=16)$ or without maintenance $(n=26)$ therapy both had a significant increase of Th17 
cells compared to the HC $(1.33 \pm 0.94 \%$ vs. $0.7 \pm 0.3 \%$, $P=0.03$ and $2.32 \pm 1.61 \%$ vs. $0.7 \pm 0.3 \%, P<0.0001)$. However, patients on maintenance therapy harbored a significantly smaller fraction of Th17 cells than untreated patients $(1.33 \pm 0.94 \%$ vs. $2.32 \pm 1.61 \%, P=$ $0.01)$.

In addition, administration of steroids had an impact on Th17 cells as there was a negative correlation of steroid dosage and percentage of Th17 cells $(r=-0.46, P=$ 0.002). A similar effect was observed for Th1 cells and steroid dosage $(r=-0.32, P=0.04)$, and so a separate analysis accounting for maintenance therapy was also performed. To assess the impact of Th17 cells on the clinical course of the disease, we stratified the patient cohort into relapse-free and relapsing patients, and identified 13 relapse-free patients and 19 relapsing patients. Two relapse-free patients and nine relapsing patients received maintenance treatment at the time of sampling. As shown before, treatment seemed to have impact on the percentage of Th17 cells. Therefore, we compared untreated relapsing patients in remission $(n=10)$ with untreated relapse-free patients in remission $(n=11)$. Th17 cells were similar between both groups (\% Th17 cells $=2.3 \pm 1.0 \%$ vs. $2.6 \pm 2.2 \%, P=0.7$ ).

\section{Disturbed balance of circulating Th17 cells and regulatory $T$ cells in active and quiescent GPA}

Regulatory T-helper-cell subsets control and limit immune responses of pro-inflammatory $\mathrm{T}$ cells. In this study, we focused on two types of regulatory $\mathrm{T}$ cells (Tregs), which were defined according to literature: $\mathrm{CD} 4{ }^{+} \mathrm{CD} 25^{\text {high }} \mathrm{C}$ D127 ${ }^{\text {low }}$ Tregs and IL- $10^{+}$Tregs $[35,36] . \mathrm{CD}^{+} \mathrm{CD} 25^{\text {high }} \mathrm{C}$ D $127^{\text {low }}$ Tregs were increased in quiescent GPA $(8.3 \pm$ $3.5 \%$ in untreated patients, $\mathrm{n}=22 ; 6.0 \pm 1.1 \%$ in treated patients, $\mathrm{n}=13)$ and active GPA $(7.0 \pm 2.8 \%, \mathrm{n}=18) \mathrm{com}$ pared to the $\mathrm{HC}(5.1 \pm 1.0 \%, \mathrm{n}=13)(P<0.006, P=0.06$, and $P=0.02$ respectively, for comparison with the $\mathrm{HC}$ ) (Figure 2A). In contrast, IL- $10^{+}$Tregs did not differ between quiescent GPA $(0.7 \pm 0.4 \%$ in untreated patients, $\mathrm{n}=26 ; 0.5 \pm 0.2 \%$ in treated patients, $\mathrm{n}=16$ ) or active GPA $(0.6 \pm 0.4 \%, \mathrm{n}=17)$ compared to the $\mathrm{HC}(0.5 \pm 0.3 \%$, $\mathrm{n}=14)(P=0.13, P=0.7$, and $P=0.52$ respectively, for comparison with the HC) (Figure 2A). As Th17 cells and Treg share developmental pathways, a reciprocal relationship has been described [37]. Accordingly, Th17 expansion is associated with Treg depletion in human SLE [22]. Therefore, a correlation analysis was performed to assess the Th17/Treg relationship in GPA. Th17 cells were positively correlated with $\mathrm{CD} 4^{+} \mathrm{CD} 25^{\text {high }} \mathrm{CD} 127^{\text {low }}$ or IL- $10^{+}$ Tregs in quiescent GPA $(r=0.34, P<0.05$ and $r=0.38$, $P=0.01)$ and active GPA $(r=0.36, P=0.14$ and $r=0.60$, $P=0.01)$ but not in the $\mathrm{HC}(r=-0.04, P=0.90$ and $r=$ $0.19, P=0.52)$. Separate analysis of GPA patients in remission stratified by maintenance treatment showed only a significant positive correlation between IL- $10^{+}$Tregs and Th17 in patients on maintenance therapy $(r=0.68, P=$ $0.004)$. Thus, a reciprocal relationship or a negative association between Th17 cells and Tregs was not found.

Ratios were calculated to assess if the balance between Th17 cells and Tregs was preserved in GPA. Importantly, Th17 expansion was not balanced by Tregs in quiescent, untreated GPA and active GPA indicated by both a higher Th17/CD2 $5^{\text {high }} \mathrm{CD} 127^{\text {low }}$ Treg ratio and Th17/IL$10^{+}$Treg ratio compared to $\mathrm{HC}$ (Figure $2 \mathrm{~B}$ ). Interestingly, in quiescent, treated GPA, only the Th17/IL- $10^{+}$Treg ratio was significantly skewed towards Th17, whereas the Th17/ CD25 ${ }^{\text {high }}$ CD $127^{\text {low }}$ Treg ratio was not different from $\mathrm{HC}$ (Figure 2B). Relapsing and relapse-free patients had comparable Th17/Treg ratios, with $0.36 \pm 0.32$ vs. $0.39 \pm 0.38(P=1.0)$ for Th17/CD $25^{\text {high }} \mathrm{CD} 127^{\text {low }}$ Treg, and $4.9 \pm 2.8$ vs. $4.3 \pm 3.8(P=0.6)$ for Th17/IL- $10^{+}$Treg.

\section{Th17 cells co-expressing IL-10 or IFN $\gamma$ are elevated in active GPA and untreated quiescent disease}

IFN $\gamma$ and IL-10 co-expression of Th17 cells was measured in a subset of GPA patients. Both IL-10 ${ }^{+} / \mathrm{IL}-17 \mathrm{~A}^{+}$ and IFN $\gamma^{+} / \mathrm{IL}-17 \mathrm{~A}^{+} \mathrm{CD} 4^{+} \mathrm{T}$ cells could be detected in GPA and HC. The percentage of IL- $10^{+} / \mathrm{IL}-17 \mathrm{~A}^{+} \mathrm{CD}^{+} \mathrm{T}$ cells was higher in untreated quiescent GPA (0.0501 \pm $0.031 \%, \mathrm{n}=23)$, but not in treated quiescent GPA $(0.0432 \pm 0.053 \%, \mathrm{n}=15)$, than in the HC $(0.0282 \pm$ $0.016 \%, \mathrm{n}=14)(P=0.007$ and $P=0.91$ respectively, for comparison with the $\mathrm{HC}$ ) (Figure $3 \mathrm{~A}$ ).

In active GPA, the percentage of the $\mathrm{IL}-10^{+} / \mathrm{IL}-17 \mathrm{~A}^{+}$ population $(0.0703 \pm 0.076 \%, \mathrm{n}=12)$ did not differ from the $\mathrm{HC}(0.0282 \pm 0.016 \%, \mathrm{n}=14, P>0.05)$ (Figure 3A).

IFN $\gamma^{+} / \mathrm{IL}-17 \mathrm{~A}^{+} \mathrm{CD} 4^{+} \mathrm{T}$ cells were significantly increased in untreated, quiescent GPA $(0.24 \pm 0.18 \%, \mathrm{n}=24, P=$ $0.001)$, but not in treated, quiescent GPA $(0.20 \pm 0.18 \%$, $\mathrm{n}=15, P=0.09)$, and in active GPA $(0.19 \pm 0.19 \%, \mathrm{n}=12$, $P<0.05)$ compared to the HC $(0.09 \pm 0.07 \%, \mathrm{n}=14)$ (Figures $3 \mathrm{~B}$ and $3 \mathrm{C}$ ). IFN $\gamma^{+} / \mathrm{IL}-10^{+} \mathrm{T}$ cells did not differ between the patients and HC (data not shown). Thus, Th17 cells producing IL-10 or IFN $\gamma$ were increased only in untreated, quiescent and active GPA.

\section{Discussion}

In patients with GPA, we observed Th17 expansion, and demonstrated that Th17 expansion is present during active disease and persists after remission has been achieved. Th17 cells seemed to be sensitive to maintenance treatment but remained elevated. Th17 expansion was not balanced either by $\mathrm{CD} 25^{\text {high }} \mathrm{CD} 127^{\text {low }}$, or by IL$10^{+}$Tregs. Finally, we observed an elevated percentage of Th17 cells expressing IL-10 or IFN $\gamma$ in untreated GPA, which possibly indicates enhanced plasticity.

Antigen-specific Th17 expansion has previously been reported in GPA $[24,26,38]$. The role of antigen-specific 


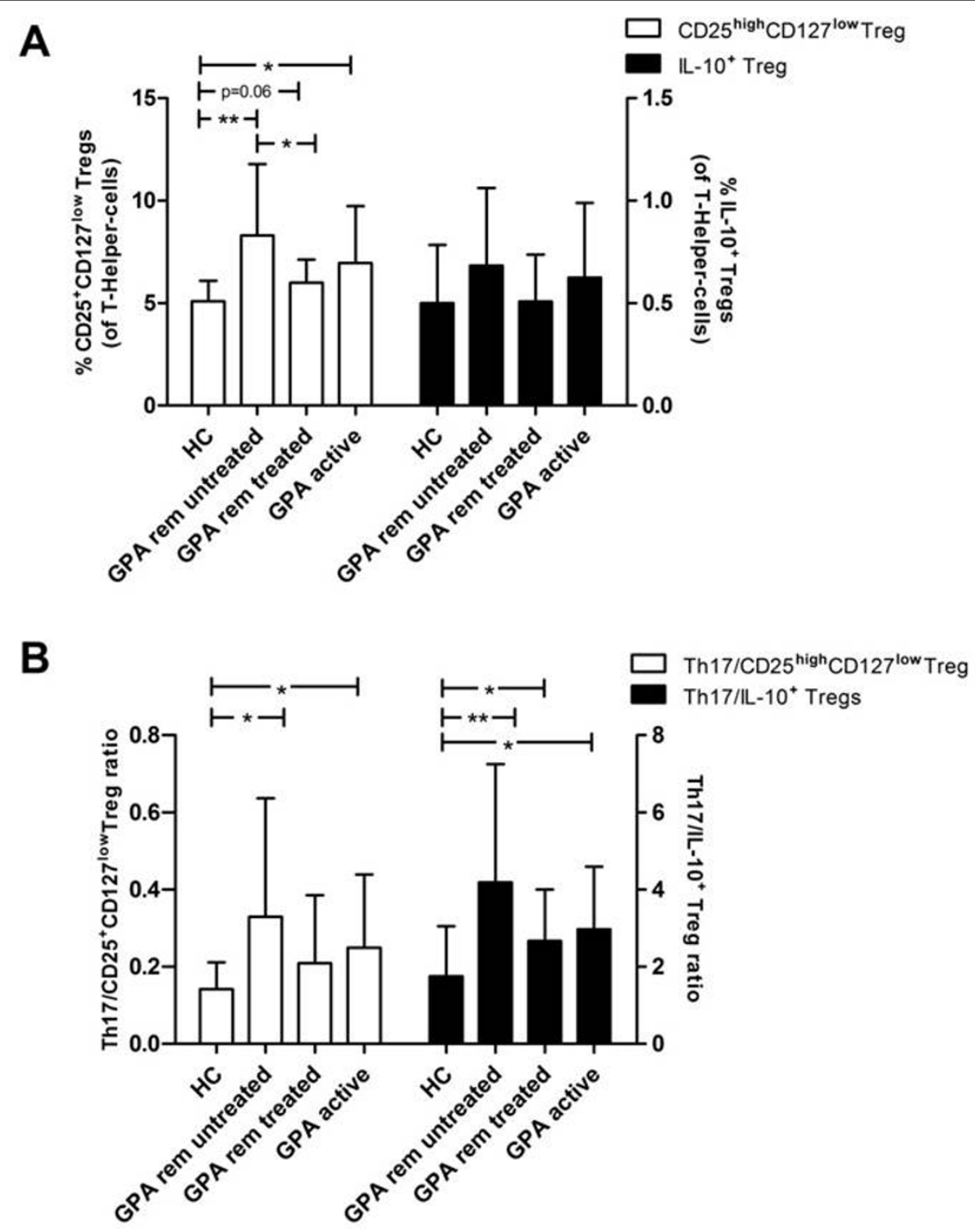

Figure 2 Regulatory T cells (Tregs) are expanded in granulomatosis with polyangiitis (GPA) but do not balance Th17 skewing. (A) The percentage of $1 \mathrm{~L}-10^{+}$Tregs was similar in active/quiescent GPA vs. healthy controls (HC), whereas $\mathrm{CD} 25^{\text {high }} \mathrm{CD} 127^{\text {low }}$ Tregs were significantly increased. (B) The Th17//L-10+ Treg ratio was significantly increased in quiescent untreated GPA (4.18 $\pm 3.07, P=0.001, \mathrm{n}=26)$, quiescent treated GPA $(2.67 \pm 1.34, P=0.02, \mathrm{n}=16)$ and active GPA $(2.97 \pm 1.63, P=0.04, \mathrm{n}=17)$ vs. HC $(1.75 \pm 1.30, \mathrm{n}=14)$. The Th17/

$\mathrm{CD} 25^{\text {high }} \mathrm{CD} 127^{\text {low }}$ Treg ratio was higher in quiescent, untreated GPA $(0.33 \pm 0.31, P=0.008, \mathrm{n}=22)$ and in active GPA $(0.25 \pm 0.19, P=0.04$, $\mathrm{n}=18)$, but not in quiescent, treated GPA $(0.21 \pm 0.18, P=0.54, \mathrm{n}=13)$ compared to $H C(0.14 \pm 0.07, \mathrm{n}=13)$. Bars represent means, error bars indicate the SD. ${ }^{*} P<0.05,{ }^{* *} P<0.006$.

T-cells in initiation of tissue inflammation is controversial. According to Ghani et al., antigen-specific T-cells are crucial initiators of tissue inflammation, whereas a recent publication by Murakami et al. suggests that antigen specificity of Th17 cells is of limited importance for the initiation of autoimmune processes [27,28]. Therefore, both auto-antigen-specific and, as determined in our study, non-specific Th17 expansion may be relevant in GPA. The driving force of Th17 cell expansion remains unclear; chronic challenge with auto-antigen or deficient function of Tregs seems likely [24,25,39]. Alternatively, high levels of cytokines promoting Th17 polarization could be an underlying cause. In line with this, increased levels of the Th17 enhancing cytokines TGF $\beta$, IL-6 and IL-23 can be found in the sera of GPA $[24,40]$. DN T-cells have been recently described as one major source of IL-17 and seem to be expanded in SLE [34]. However, in GPA patients, levels of DN T-cells 


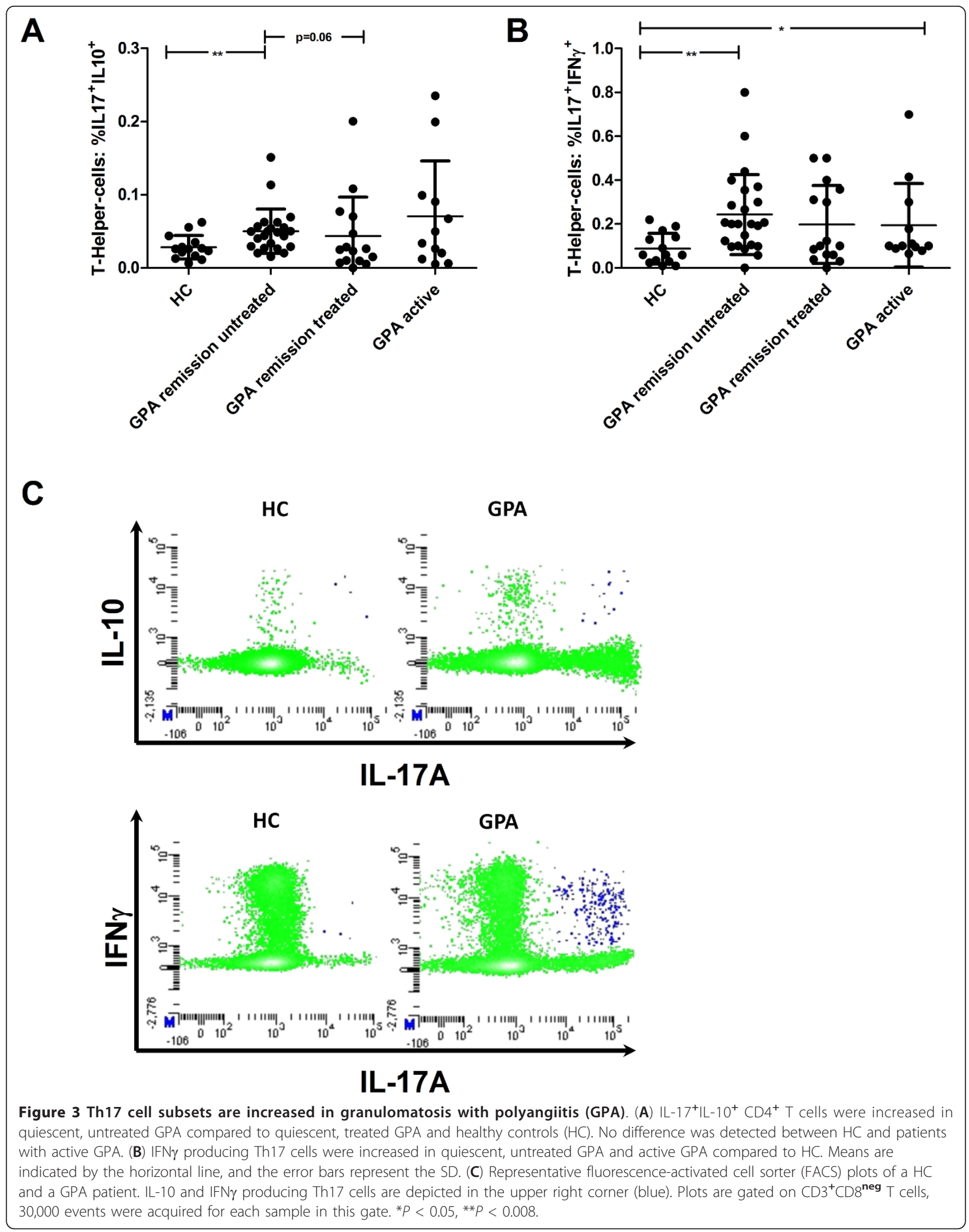


appeared similar to those in the $\mathrm{HC}$, and Th17 cells did not correlate with DN T-cells. Therefore, the nature of Th17 expansion might be different in SLE when compared to GPA.

We found similar, elevated levels of circulating Th17 cells both in patients with active and quiescent GPA, implying that there was no association with disease activity. This is in contrast to findings in SLE and giant cell arteritis (GCA) where a close relationship of IL-17A ${ }^{+}$ $\mathrm{T}$ cell numbers and disease activity is reported $[19,22,41]$. Interestingly, IFN $\gamma^{+} \mathrm{T}$-cells were significantly diminished during active GPA compared to quiescent GPA, suggesting an inverse association with disease activity. IFN $\gamma^{+}$ T-cells are found in inflamed lesions in GPA and recruitment from the circulation may therefore explain the reduction during the active phase of the disease [10,42-44]. In GCA, steroid therapy during active disease reduces Th17 cell numbers very efficiently and the reduction is maintained during remission [19]. Indeed, in our study a negative association between steroid dose and Th17 cells was observed, indicating some sensitivity to steroids. However, in contrast to GCA, a persistent reduction to normal levels is not achieved in GPA. Th17 cells remained elevated in quiescent GPA patients on maintenance therapy, and even more so in GPA patients in whom maintenance therapy was previously withdrawn. This might have implications for the disease course. There is circumstantial evidence that persistent Th17 expansion is associated with a higher tendency to relapse. In a study by Nogueira et al., five patients were prospectively followed, of whom two showed elevated IL-17A serum levels after remission was achieved. Only those two patients relapsed within 15 months after first presentation, whereas the other three remained in remission (follow-up time 15, 20 and 23 months) [24]. In our study, however, we could not link Th17 expansion to relapse propensity.

The skewing towards Th17 was not sufficiently balanced by $\mathrm{CD} 4^{+} \mathrm{CD} 25^{\text {high }} \mathrm{CD} 127^{\text {low }}$ or IL-10-producing Tregs. A disturbed balance of pro-inflammatory and anti-inflammatory $\mathrm{T}$ cell subsets with a shift towards pro-inflammatory subsets is suggested to be an important pathogenic mechanism of autoimmunity [45]. Accordingly, the observed shift of the Th17/Treg ratio in GPA might point to an increased risk for exaggerated immune responses in case of trigger events such as infections [46]. Indeed, infections may provoke relapses in patients with GPA $[47,48]$. To a certain extent, patients on maintenance therapy showed a normalization of the Th17/Treg ratio.

We detected an increased fraction of IL- $17^{+} \mathrm{IFN} \gamma^{+}$and IL17 ${ }^{+} \mathrm{IL}-10^{+} \mathrm{T}$ cells in GPA. IL- $17^{+} \mathrm{IFN} \gamma^{+}$are described in human studies as a very potent pro-inflammatory $\mathrm{T}$ cell subset with enhanced migratory capacity [49-51].
Thus, IL- $17^{+} \mathrm{IFN} \gamma^{+}$might have a role in tissue inflammation in GPA. Moreover, it is known that T cells have the capacity to convert into other $\mathrm{T}$ cell lineages [50,52]. Plasticity of Th17 and Treg might be an important factor in autoimmune diseases [53]. Protective Treg converting into harmful Th17 cells could promote pro-inflammatory conditions and be fatal for immune homeostasis [54]. Plasticity is a transient, dynamic process and doublepositive IL- $17^{+} \mathrm{IL}-10^{+} \mathrm{T}$ cells can be found temporarily during conversion as part of this process [53]. The exact role and significance of these Th17 subsets remains to be studied. [21,49,50,53].

In conclusion, we provide evidence for a persistent, unbalanced expansion of Th17 cells and Th17 cell subsets which is partly reversed by maintenance therapy in GPA. Our findings may indicate a pathogenic role of Th17 cells in GPA.

\section{Conclusions}

Th17 cells and Th17 subsets are expanded in GPA irrespective of disease activity. Furthermore, the balance of Th17 cells and Tregs seems to be disturbed. Maintenance therapy does not normalize Th17 expansion, which persists after therapy is ceased. The significance of Th17 subsets producing IFN $\gamma$ and/or IL-10 should be studied further.

\section{Abbreviations \\ ANCA: anti-neutrophil-cytoplasmic antibodies; FACS: fluorescence-activated cell sorter; GCA: giant cell arteritis; GPA; granulomatosis with polyangiitis; $\mathrm{HC}$ : healthy controls; IFNY: interferon gamma; MPO: myeloperoxidase; PBMC: peripheral blood mononuclear cells; PMA: phorbol-12-myristat-13-acetate; PR3: proteinase-3; RA: rheumatoid arthritis; SLE: systemic lupus erythematosus; TGF $\beta$ : transforming growth factor beta; Th17 cells: T-helper- 17-cells; Treg: regulatory $T$ cell.}

\section{Acknowledgements}

This work was funded by a grant of the Deutsche Forschungsgemeinschaft (DFG), Wi-3723/1-1 (B.W.). The authors thank Henk van Rie, Nele Bijnens and Petra Heerings for excellent technical assistance.

\section{Author details}

'Department of Internal Medicine, Division of Clinical and Experimental Immunology, University Hospital Maastricht, PO Box 5800, Maastricht, 6202 AZ, The Netherlands. ${ }^{2}$ Department of Nephrology, University Duisburg-Essen, Hufelandstr. 55, Essen, 45127, Germany. ${ }^{3}$ Laboratory of Clinical Immunology, Maastricht University Medical Center, PO Box 5800, Maastricht, 6202 AZ, The Netherlands.

\section{Authors' contributions}

All authors contributed to the design, acquisition and interpretation of data. BW performed the statistical analysis. BW, MT, MH, JD, PvP, OW and JWCT drafted the manuscript. BW carried out flow cytometry. BW and JWCT assessed and participated in the interpretation of the clinical data. All authors read and approved the final manuscript.

\section{Competing Interests}

The authors declare that they have no competing interests.

Received: 24 February 2012 Revised: 14 August 2012 Accepted: 28 August 2012 Published: 18 October 2012 


\section{References}

1. Tervaert JW, Goldschmeding R, Elema JD, Limburg PC, van der Giessen M, Huitema MG, Koolen MI, Hene RJ, The TH, van der Hem GK, von dem Borne AEGK, Kallenberg CGM: Association of autoantibodies to myeloperoxidase with different forms of vasculitis. Arthritis Rheum 1990, 33:1264-1272.

2. Tervaert JW, van der Woude FJ, Fauci AS, Ambrus JL, Velosa J, Keane WF, Meijer S, van der Giessen M, The TH, van der Hem GK, Kallenberg CGM: Association between active Wegener's granulomatosis and anticytoplasmic antibodies. Arch Intern Med 1989, 149:2461-2465.

3. Wilde B, van Paassen P, Witzke O, Tervaert JW: New pathophysiological insights and treatment of ANCA-associated vasculitis. Kidney Int 2011, 79:599-612.

4. Brouwer E, Tervaert JW, Horst G, Huitema MG, van der Giessen M, Limburg PC, Kallenberg CG: Predominance of IgG1 and IgG4 subclasses of anti-neutrophil cytoplasmic autoantibodies (ANCA) in patients with Wegener's granulomatosis and clinically related disorders. Clin Exp Immunol 1991, 83:379-386.

5. Lamprecht $P$, Csernok E, Gross WL: Effector memory T cells as driving force of granuloma formation and autoimmunity in Wegener's granulomatosis. J Intern Med 2006, 260:187-191.

6. Wilde B, Thewissen M, Damoiseaux J, van Paassen P, Witzke O, Tervaert JW: $T$ cells in ANCA-associated vasculitis: what can we learn from lesional versus circulating T cells? Arthritis Res Ther 2010, 12:204.

7. Wilde $B$, van Paassen $P$, Damoiseaux J, Heerings-Rewinkel $P$, van Rie $H$, Witzke O, Tervaert JW: Dendritic cells in renal biopsies of patients with ANCA-associated vasculitis. Nephrol Dial Transplant 2009, 24:2151-2156.

8. Abdulahad WH, Stegeman CA, van der Geld YM, Doornbos-van der Meer B, Limburg PC, Kallenberg CG: Functional defect of circulating regulatory CD4+ T cells in patients with Wegener's granulomatosis in remission Arthritis Rheum 2007, 56:2080-2091.

9. Abdulahad WH, van der Geld YM, Stegeman CA, Kallenberg CG: Persistent expansion of CD4+ effector memory T cells in Wegener's granulomatosis. Kidney Int 2006, 70:938-947.

10. Lamprecht $P$, Moosig F, Csernok E, Seitzer U, Schnabel A, Mueller A Gross WL: CD28 negative T cells are enriched in granulomatous lesions of the respiratory tract in Wegener's granulomatosis. Thorax 2001 56:751-757.

11. Popa ER, Franssen CF, Limburg PC, Huitema MG, Kallenberg CG, Tervaert JW: In vitro cytokine production and proliferation of T cells from patients with anti-proteinase 3- and antimyeloperoxidase-associated vasculitis, in response to proteinase 3 and myeloperoxidase. Arthritis Rheum 2002, 46:1894-1904.

12. Popa ER, Stegeman CA, Bos NA, Kallenberg CG, Tervaert JW: Differential Band T-cell activation in Wegener's granulomatosis. J Allergy Clin Immunol 1999, 103:885-894

13. Stegeman CA, Tervaert JWC, Huitema MG, Kallenberg CGM: Serum markers of T-cell activation in relapses of Wegeners granulomatosis. Clin Exp Immunol 1993, 91:415-420.

14. Wilde B, Dolff S, Cai X, Specker C, Becker J, Totsch M, Costabel U, Durig J, Kribben A, Tervaert JW, Schmid KW, Witzke O: CD4+CD25+ T-cell populations expressing CD134 and GITR are associated with disease activity in patients with Wegener's granulomatosis. Nephrol Dial Transplant 2009, 24:161-171.

15. Bettelli E, Korn T, Kuchroo VK: Th17: the third member of the effector T cell trilogy. Curr Opin Immunol 2007, 19:652-657.

16. Weaver CT, Harrington LE, Mangan PR, Gavrieli M, Murphy KM: Th17: An effector CD4 T cell lineage with regulatory T cell ties. Immunity 2006, 24:677-688.

17. Hemdan NYA, Birkenmeier G, Wichmann G, Abu El-Saad AM, Krieger T, Conrad K, Sack U: Interleukin-17-producing T helper cells in autoimmunity. Autoimmun Rev 2010, 9:785-792.

18. Korn T, Oukka M, Kuchroo V Bettelli E. Th17 cells: effector T cells with inflammatory properties. Semin Immunol 2007, 19:362-371.

19. Deng J, Younge BR, Olshen RA, Goronzy JJ, Weyand CM: Th17 and Th1 T-Cell responses in giant cell arteritis. Circulation 2010, 121:906-915.

20. Miossec P: Interleukin-17 and Th17 cells: From adult to juvenile arthritisNow it is serious! Arthritis Rheum 2011, 63:2168-2171.

21. von Vietinghoff $S$, Ley K: Interleukin 17 in vascular inflammation. Cytokine Growth Factor Rev 2010, 21:463-469.
22. Yang J, Chu Y, Yang X, Gao D, Zhu L, Yang X, Wan L, Li M: Th17 and natural Treg cell population dynamics in systemic lupus erythematosus. Arthritis Rheum 2009, 60:1472-1483.

23. Gan P-Y, Steinmetz OM, Tan DSY, O'Sullivan KM, Ooi JD, Iwakura Y, Kitching AR, Holdsworth SR: Th17 cells promote autoimmune antimyeloperoxidase glomerulonephritis. J Am Soc Nephrol 2010, 21:925-931.

24. Nogueira E, Hamour S, Sawant D, Henderson S, Mansfield N, Chavele K-M Pusey CD, Salama AD: Serum IL-17 and IL-23 levels and autoantigenspecific Th17 cells are elevated in patients with ANCA-associated vasculitis. Nephrol Dial Transplant 2010, 25:2209-2217.

25. Abdulahad WH, Stegeman CA, Limburg PC, Kallenberg CG: Skewed distribution of Th17 lymphocytes in patients with Wegener's granulomatosis in remission. Arthritis Rheum 2008, 58:2196-2205.

26. Fagin U, Csernok E, Muller A, Pitann S, Fazio J, Krause K, Bremer $P$ Freissmuth EW, Moosig F, Gross WL, Lamprecht P: Distinct proteinase 3induced cytokine patterns in Wegener's granulomatosis, Churg-Strauss syndrome, and healthy controls. Clin Exp Rheumatol 2011, 29:S57-S62.

27. Ghani S, Feuerer M, Doebis C, Lauer U, Loddenkemper C, Huehn J, Hamann A, Syrbe U: T cells as pioneers: antigen-specific $T$ cells condition inflamed sites for high-rate antigen-non-specific effector cell recruitment. Immunology 2009, 128:e870-e880

28. Murakami M, Okuyama Y, Ogura H, Asano S, Arima Y, Tsuruoka M, Harada M, Kanamoto M, Sawa Y, Iwakura Y, Takatsu K, Kamimura D, Hirano T: Local microbleeding facilitates IL-6- and IL-17-dependent arthritis in the absence of tissue antigen recognition by activated T cells. J Exp Med 2011, 208:103-114.

29. Watts R, Lane S, Hanslik T, Hauser T, Hellmich B, Koldingsnes W, Mahr A Segelmark M, Cohen-Tervaert JW, Scott D: Development and validation of a consensus methodology for the classification of the ANCA-associated vasculitides and polyarteritis nodosa for epidemiological studies. Ann Rheum Dis 2007, 66:222-227.

30. Leavitt RY, Fauci AS, Bloch DA, Michel BA, Hunder GG, Arend WP Calabrese LH, Fries JF, Lie JT, Lightfoot RW, Masi AT, McShane DJ, Mills JA, Stevens MB, Wallace SL, Zvaifler NJ: The American College of Rheumatology 1990 criteria for the classification of Wegener's Granulomatosis. Arthritis Rheum 1990, 33:1101-1107.

31. Jennette JC, Falk RJ, Andrassy K, Bacon PA, Churg J, Gross WL, Hagen EC, Hoffman GS, Hunder GG, Kallenberg CG, McCluskey RT, Sinico RA, Rees AJ, Es LAV, Waldherr R, Wiik A: Nomenclature of systemic vasculitides. Proposal of an international consensus conference. Arthritis Rheum 1994 37:187-192.

32. Boomsma MM, Stegeman CA, van der Leij MJ, Oost W, Hermans J, Kallenberg CG, Limburg PC, Tervaert JW: Prediction of relapses in Wegener's granulomatosis by measurement of antineutrophil cytoplasmic antibody levels: a prospective study. Arthritis Rheum 2000, 43:2025-2033.

33. Hellmich B, Flossmann O, Gross WL, Bacon P, Willem Cohen-Tervaert J Guillevin L, Jayne D, Mahr A, Merkel PA, Raspe H, Scott DGl, Witter J, Yazici H, Luqmani RA, on behalf of the European Vasculitis Study G: EULAR recommendations for conducting clinical studies and/or clinical trials in systemic vasculitis: focus on anti-neutrophil cytoplasm antibodyassociated vasculitis. Ann Rheum Dis 2007, 66:605-617

34. Crispin JC, Oukka M, Bayliss G, Cohen RA, Van Beek CA, Stillman IE, Kyttaris VC, Juang YT, Tsokos GC: Expanded double negative T Cells in patients with systemic lupus erythematosus produce IL-17 and infiltrate the kidneys. J Immunol 2008, 181:8761-8766.

35. Mauri $C$, Carter N: Is there a feudal hierarchy amongst regulatory immune cells? More than just Tregs. Arthritis Res Ther 2009, 11:237

36. Seddiki N, Santner-Nanan B, Martinson J, Zaunders J, Sasson S, Landay A, Solomon M, Selby W, Alexander SI, Nanan R, Kelleher A, de St. Groth BF: Expression of interleukin (IL)-2 and IL-7 receptors discriminates between human regulatory and activated T cells. J Exp Med 2006, 203:1693-1700.

37. Bettelli E, Korn T, Oukka M, Kuchroo VK: Induction and effector functions of TH17 cells. Nature 2008, 453:1051-1057.

38. Abdulahad WH, Stegeman CA, Limburg PC, Kallenberg CG: Skewed distribution of Th17 lymphocytes in patients with Wegener's granulomatosis in remission. Arthritis Rheum 2008, 58:2196-2205.

39. Morgan MD, Day CJ, Piper KP, Khan N, Harper L, Moss PA, Savage COS: Patients with Wegener's granulomatosis demonstrate a relative deficiency and functional impairment of T-regulatory cells. Immunology 2010, 130:64-73. 
40. Kekow J, Szymkowiak CH, Sticherling M, Schroder JM, Christophers E, Gross WL: Pro- and anti-inflammatory cytokines in primary systemic vasculitis. Adv Exp Med Biol 1993, 336:341-344.

41. Shah K, Lee WW, Lee SH, Kim SH, Kang SW, Craft J, Kang I: Dysregulated balance of Th17 and Th1 cells in systemic lupus erythematosus. Arthritis Res Ther 2010, 12:R53.

42. Komocsi A, Lamprecht P, Csernok E, Mueller A, Holl-Ulrich K, Seitzer U, Moosig F, Schnabel A, Gross WL: Peripheral blood and granuloma CD4(+) CD28(-) T cells are a major source of interferon-gamma and tumor necrosis factor-alpha in Wegener's granulomatosis. Am J Pathol 2002, 160:1717-1724.

43. Csernok E, Trabandt A, Muller A, Wang GCC, Moosig F, Paulsen J, Schnabel A, Gross WL: Cytokine profiles in Wegener's granulomatosis Predominance of type 1 (Th1) in the granulomatous inflammation. Arthritis Rheum 1999, 42:742-750.

44. Muller A, Trabandt A, Gloeckner-Hofmann K, Seitzer U, Csernok E, Schonermarck U, Feller AC, Gross WL: Localized Wegener's granulomatosis: Predominance of CD26 and IFN-gamma expression. J Pathol 2000, 192:113-120

45. Afzali B, Lombardi G, Lechler RI, Lord GM: The role of T helper 17 (Th17) and regulatory $\mathrm{T}$ cells (Treg) in human organ transplantation and autoimmune disease. Clin Exp Immunol 2007, 148:32-46.

46. Ishigame H, Kakuta S, Nagai T, Kadoki M, Nambu A, Komiyama Y, Fujikado N, Tanahashi Y, Akitsu A, Kotaki H, Sudo K, Nakae S, Sasakawa C, Iwakura Y: Differential roles of interleukin-17A and $-17 \mathrm{~F}$ in host defense against mucoepithelial bacterial infection and allergic responses. Immunity 2009, 30:108-119.

47. Pinching AJ, Rees AJ, Pussell BA, Lockwood CM, Mitchison RS, Peters DK Relapses in Wegener's granulomatosis: the role of infection. $\mathrm{Br}$ Med J 1980, 281:836-838

48. Stegeman CA, Tervaert JW, Sluiter WJ, Manson WL, de Jong PE, Kallenberg CG: Association of chronic nasal carriage of Staphylococcus aureus and higher relapse rates in Wegener granulomatosis. Ann Intern Med 1994, 120:12-17.

49. Boniface K, Blumenschein WM, Brovont-Porth K, McGeachy MJ, Basham B, Desai B, Pierce R, McClanahan TK, Sadekova S, de Waal Malefyt R: Human Th17 cells comprise heterogeneous subsets including IFN-g producing cells with distinct properties from the Th1 lineage. J Immunol 2010, 185:679-687.

50. Eid RE, Rao DA, Zhou J, Lo S-fL, Ranjbaran H, Gallo A, Sokol SI, Pfau S, Pober JS, Tellides G: Interleukin-17 and Interferon-gamma are produced concomitantly by human coronary artery-infiltrating $\mathrm{T}$ cells and act synergistically on vascular smooth muscle cells. Circulation 2009, 119:1424-1432.

51. Kebir H, Ifergan I, Alvarez Jl, Bernard M, Poirier J, Arbour N, Duquette $P$, Prat A: Preferential recruitment of interferon- $\gamma$-expressing $\mathrm{TH} 17$ cells in multiple sclerosis. Ann Neurol 2009, 66:390-402.

52. Koenen HJPM, Smeets RL, Vink PM, van Rijssen E, Boots AMH, Joosten I: Human CD25highFoxp3pos regulatory T cells differentiate into IL-17producing cells. Blood 2008, 112:2340-2352.

53. Annunziato F, Romagnani S: The transient nature of the Th17 phenotype. Eur J Immunol 2010, 40:3312-3316.

54. Zhou X, Bailey-Bucktrout SL, Jeker LT, Penaranda C, Martinez-Llordella M, Ashby M, Nakayama M, Rosenthal W, Bluestone JA: Instability of the transcription factor Foxp3 leads to the generation of pathogenic memory T cells in vivo. Nat Immunol 2009, 10:1000-1007.

doi:10.1186/ar4066

Cite this article as: Wilde et al.: Th17 expansion in granulomatosis with polyangiitis (Wegener's): the role of disease activity, immune regulation and therapy. Arthritis Research \& Therapy 2012 14:R227.

\section{Submit your next manuscript to BioMed Central and take full advantage of:}

- Convenient online submission

- Thorough peer review

- No space constraints or color figure charges

- Immediate publication on acceptance

- Inclusion in PubMed, CAS, Scopus and Google Scholar

- Research which is freely available for redistribution

Submit your manuscript at www.biomedcentral.com/submit
Biomed Central 